\title{
Morpho-anatomy of the otic region in carapid fishes: eco-morphological study of their otoliths
}

\author{
E. Parmentier* + , P. VAndewalle* And F. Lagardère $\dagger$ \\ * Laboratory of Functional and Evolutionary Morphology, Chemistry Institute B6, \\ University of Liège, Sart-Tilman, B-4000 Liège, Belgium and $\dagger$ CREMA-L'Houmeau \\ (CNRS-IFREMER), BP 5, F-17137 L'Houmeau, France
}

(Received 9 September 2000, Accepted 8 November 2000)

\begin{abstract}
Carapid species are characterized by so-called otophysical structures (sonic muscles, broad first apophyses covering the anterior part of the swimbladder, etc.) The family includes pelagic (Pyramodon and Snyderidia) and benthic (Echiodon) species and ones that are either commensal with (Onuxodon, Carapus) or parasites of (Encheliophis) invertebrates (sea cucumbers, etc). The aim of the present work was to seek possible relationships between the structures of the inner ear (particularly the sagitta) on the one hand and otophysical structures and lifestyles within the Carapidae family. In the eight species studied, the otic cavity is wide, the saccular otosac and its sagitta are particularly developed. The sacculi touch each other on the median line. A comparison of the inner ear structures reveals notably that the species with the most developed sagitta and sacculus are those with the largest parapophyses and have a commensal or parasitic lifestyle.

(C) 2001 The Fisheries Society of the British Isles
\end{abstract}

Key words: otolith; inner ear; carapidae; ecomorphology; skull.

\section{INTRODUCTION}

The major roles associated with the otoliths of the inner ear in teleosts are sound transduction and participation in maintaining static and dynamic equilibrium (Lowenstein, 1971; Tavolga, 1971; Platt \& Popper, 1981; Schuijf, 1981; Popper, 1982; Gauldie, 1988). These inner ear functions result in otolith shapes known to be species-specific. This is particularly true of the saccular otolith (Nolf, 1985; Lombarte \& Morales-Nin, 1995). Yet intra-species variation of sagitta shape has been observed also (Nolf, 1985; Lombarte \& Castellon, 1991) and has been attributed to adaptation to different habitats (Wilson, 1985). Furthemore, Nolf $(1985,1993)$ reports examples of convergence in otolith shape among unrelated teleost families sharing similar ecological niches during their life span.

There were two reasons for studying the inner ear and otoliths among the Carapidae (Ophidiiformes):

(i) Courtenay \& McKittrick (1970); Courtenay (1971), and Howes (1982) have shown the presence of sonic muscles in various ophidiiform species. Those of the carapid are particularly long. They insert onto the anterior region of the swimbladder, run ventrally along the neurocranium, and attach to the orbit. Furthermore, the anterior part of the swimbladder is protected by the first pair of parapophyses, which are particularly broad in species of the genera Carapus,

\footnotetext{
\$Author to whom correspondence should be addressed. Tel.: (32) 43665024; fax: (32) 43663715; email:
} E.Parmentier@ulg.ac.be 
Encheliophis, and Onuxodon (Markle \& Olney, 1990). Onuxodon species are characterized by the presence of a small element (the rocker bone) that may strike against the anterior part of the swimbladder. According to Courtenay \& McKittrick (1970), this set of structures could be associated with sound production. In this context, the inner ears of carapid fish might be expected to show special features.

(ii) Another advantage of carapid fish is the diversity of their lifestyles. Four habitats can be distinguished. Pyramodon and Snyderidia species swim in open water and are pelagic, Echiodon species live in shelf and slope water and are considered benthic. The lifestyle of Onuxodon, Carapus, and Encheliophis (Trott, 1981; Markle \& Olney, 1990; Parmentier et al., 2000a) is peculiar. These three genera include species that can penetrate into and live inside various invertebrates such as sea cucumbers, starfish, and bivalves. Thus their environment is restricted. Carapus and Onuxodon are commensal, which necessarily implies moving outside the host to obtain food (Parmentier et al., 2000a). Encheliophis species eat the internal tissues of their holothurian hosts (Parmentier et al., $2000 a$ ) and thus sojourn longer inside the host. Life in these different habitats could require different sound perception, equilibration, and swimming capacities. An ecomorphological approach might show that the shape of the otoliths is not merely a compromise between the different functions in which they participate, but also a reflection of the influence of environmental factors. Furthermore, a study of closely related species would limit the extent of variations due to genetic causes (Motta \& Kotrschal, 1992; Motta et al., 1995), which according to Wilson (1985) and Lombarte \& Castellon (1991) constitute the main factor explaining variations in otolith shape.

Previous descriptions of carapid otoliths can be found in Trott (1970), Nolf (1980), and Berdar et al. (1995). They require further development to provide an improved picture of the whole otic area and a better basis for studying otolith function. The present work is an ecomorphological study of the otic region, especially the labyrinths and sagittae, these being the most developed otoliths in non-ostariophysi (Platt \& Popper, 1981). The aims were (i) to determine whether these structures show peculiarities linked with the presence of organs associated with sound production and (ii) to investigate to what extent the different ecological niches affect the otic region and otic organ. This paper contains a detailed description of the structures of Carapus boraborensis (Kaup, 1856), compared with those of C. homei (Richardson, 1844), C. dubius (Putnam, 1874), Encheliophis gracilis (Bleeker, 1856), Echiodon drummondi Thompson, 1837, Onuxodon fowleri (Smith, 1955), Snyderidia canina (Gilbert, 1905), and Pyramodon punctatus (Regan, 1914).

\section{MATERIALS AND METHODS}

Specimens of $C$. boraborensis (10 specimens, $\left.L_{\mathrm{T}}: 13-30 \mathrm{~cm}\right)$, C. homei $\left(7\right.$ specimens, $L_{\mathrm{T}}$ 8-17 cm), E. gracilis ( 3 specimens, $\left.L_{\mathrm{T}} 16-24 \mathrm{~cm}\right)$, and $O$. fowleri $\left(3\right.$ specimens, $\left.L_{\mathrm{T}} 6-9 \mathrm{~cm}\right)$ were sampled from the Bismarck Sea (Papua New Guinea) or from around Moorea (French Polynesia). Three specimens of Echiodon drummondi $\left(L_{\mathrm{T}} 20 \mathrm{~cm}\right)$ were fished from the North Sea and two specimens of C. dubius $\left(L_{\mathrm{T}} 9 \mathrm{~cm}\right)$ from the Bay of La Paz (Gulf of California, Pacific Ocean). Other specimens were provided by museums: Snyderidia canina $\left(L_{\mathrm{T}} 17 \mathrm{~cm}\right)$ came from Japanese waters (University of Kyoto, 9669) and 
Pyramodon punctatus $\left(L_{\mathrm{T}} 25 \mathrm{~cm}\right)$ from the east coast of Australia (Australian Museum, I.29744001). All fishes were dissected and examined with a Wild M10 (Leica) binocular equipped with a camera lucida. Whole otoliths were dehydrated in an oven and coated by Au-Pd pulverization (Balzers SCD-30). Photographs were taken with a scanning electron microscope (JEOL, JSM-840) under a $19-\mathrm{kV}$ acceleration voltage.

\section{RESULTS}

\section{OTIC SKULL}

The otic capsule of carapid fishes is very wide. The bones of which it is composed are characterized by major overlaps that reinforce its rigidity (Fig. 1). In $C$. boraborensis, the capsule is limited dorsally by the frontals, then by the joined parietals covering the anterior part of the supraoccipital. The latter is bordered by the epiotics. Laterally, the otic cavity is formed by the prootics and pterotics in contact with the well-developed intercalars. Ventrally, it is limited by the basioccipital which seems to be divided anteriorly in two parts by the posterior part of the parasphenoid. Posteriorly, the foramen magnum is surrounded only by the exoccipitals, surmounted by the supraoccipital.

Viewed internally (Figs 1 and 2), the cavity floor is limited posteriorly by the basioccipital and anteriorly by the bridge of the prootic. These bones surround the rest of the chord and divide the inferior part of the otic cavity in two. The separation is narrow at the back and broadens at the level of the prootics (Fig. 2). The basioccipital, furthermore, displays a median internal stem, the end of which marks the lower limit of the myelencephalon. Ventrally, its posterior part is joined to the exoccipitals to form a narrow window, the foramen of the asteriscus. The prootics also display a backward-pointing internal prootic wing. It is preceded by a plate that surmounts the foramina of the trigeminal and facial nerves. The otic cavity is further characterized by the presence of two narrow bony arches through which pass the semicircular canals (see below), one at the level of the prootic, the other in the angle of the epiotic (posterior arch).

In the other species, the variations observed concern the relative sizes of the components. In $S$. canina and $P$. punctatus, the prootic wings are longer than those of $C$. boraborensis, whereas in $O$. fowleri and Echiodon drummondi they are shorter. In $S$. canina and $P$. punctatus, the bones are thicker and the sutures between the frontals, parietals, and supraoccipital are less pronounced than in the other species. This character, already mentioned by Strasburg (1965) and Williams (1983), confers marked rigidity to the whole. Figure 3 shows the neurocrania of the various species adjusted proportionately to the same length assigned to the distance extending from the front of the mesethmoid to the back of the basioccipital. This adjustment enables evaluation of the relative sizes of the otic capsules. Lines A and B are determined by the foramen of the nerves of the trigemino-facial chamber and thus limit the otic cavity in front. Line C provides a posterior limit of the cavity, extending through the vagus foramen posteriorly. This figure shows clearly that the otic cavities are proportionately larger in the commensal species (C. boraborensis, C. homei and C. dubius) and parasitic ones (Encheliophis gracilis) than in the benthic (Echiodon drummondi) and pelagic species (S. canina and P. punctatus). In Encheliophis gracilis and the Carapus species, the length and height of the otic region are proportionately 


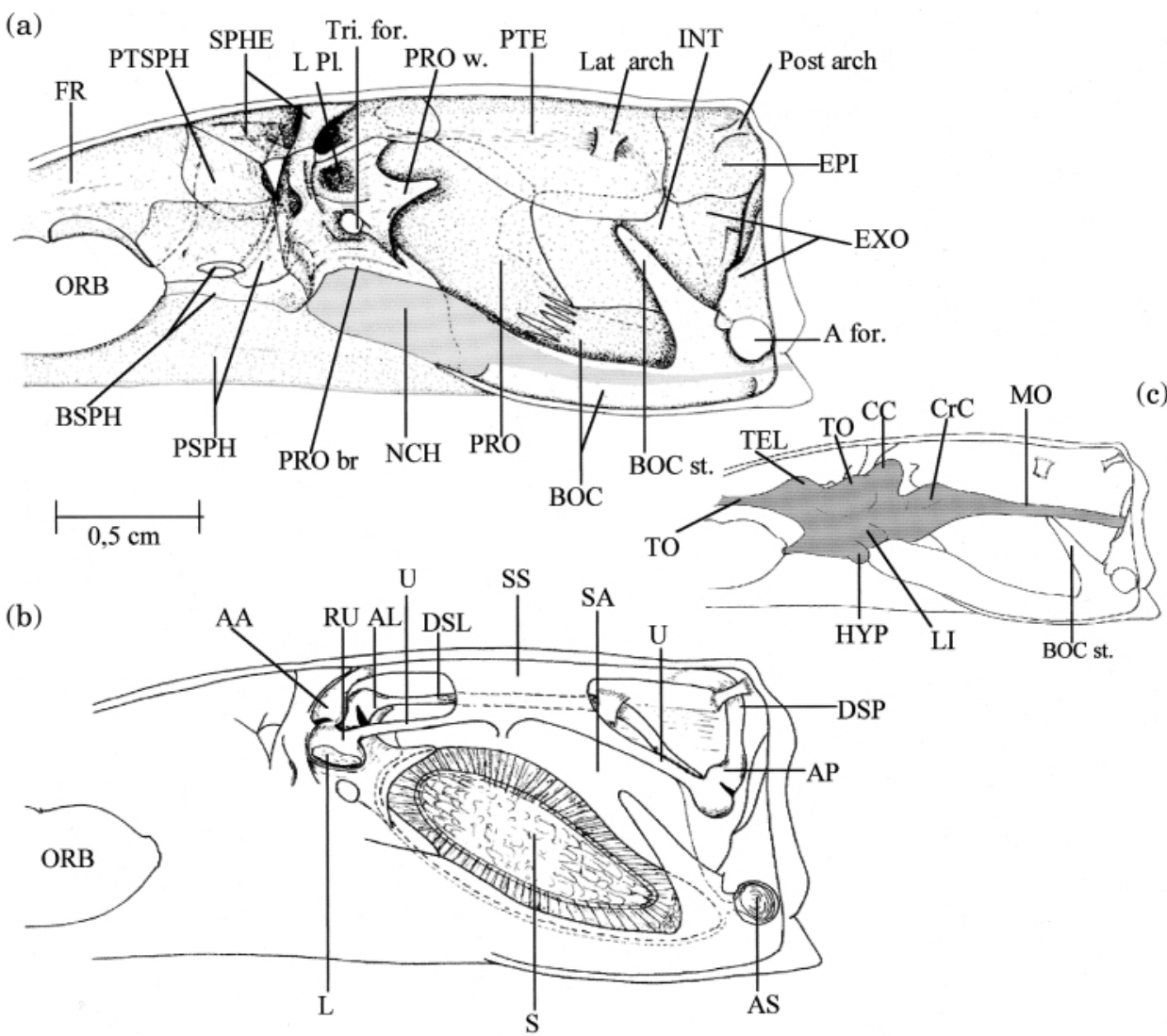

FIG. 1. Internal sagittal view of the brain case (a), with the positions of the inner ear (b) and brain (c) in Carapus boraborensis. Dotted lines indicate the zones of overlap between bones. In light grey, the notochord $(\mathrm{NCH})$. AA, ampulla anterior; A for., asteriscus foramen; AL, ampulla lateralis; $\mathrm{AP}$, ampulla posterior; AS, asteriscus; BOC, basioccipital; BOC st., basioccipital stem; BSPH, basisphenoid; CC, corpus cerebelli; CrC, crista cerebellis; DSA, ductus semicircularis anterior; DSL, ductus semicircularis lateralis; DSP, ductus semicircularis posterior; EPI, epiotic; EXO, exoccipital; FR, frontal; HYP, hypophysis; INT, intercalarium; L, lapillus; L. Pl., lapillus plate; LA, lagena; Lat arch, lateral arch; LETH, lateral ethmoid; LI, lobus inferior; METH, mesethmoid; MO, medulla oblongata; NCH, notochord; n.VIII, nerve VIII; Post arch, posterior arch; PRO, prootic; PRO br, prootic bridge; PRO w., prootic wing; PSPH, parasphenoid; PTE, pterotic; PTSPH, pterosphenoid; RU, recessus utriculi; S, sagitta; SA, sacculus; SPHE, sphenotic; SS, sinus superior; TEL, telencephalon; TO, tectum opticum; Tri. for., trigeminofacial foramen; U, utriculus.

comparable. In $O$. fowleri, the otic cavity appears shorter but deeper. The basioccipital and prootics are very rounded ventrally. In Echiodon drummondi, $S$. canina, and $P$. punctatus, the cavity floor is flatter than in the commensal and parasitic species.

\section{INNER EAR AND OTOLITH: LOCATION AND DESCRIPTION}

The membranous labyrinths description is based on $C$. boraborensis. It appears well developed. They occupy nearly the entire otic cavity: the metencephalon hardly reaches the back of the prootic bridge. Only the narrow myelencephalon crosses the otic cavity, separating the left ear from the right one at the level of the partes superiores (semi-circular canals and utricles) [Fig. 1(c) 


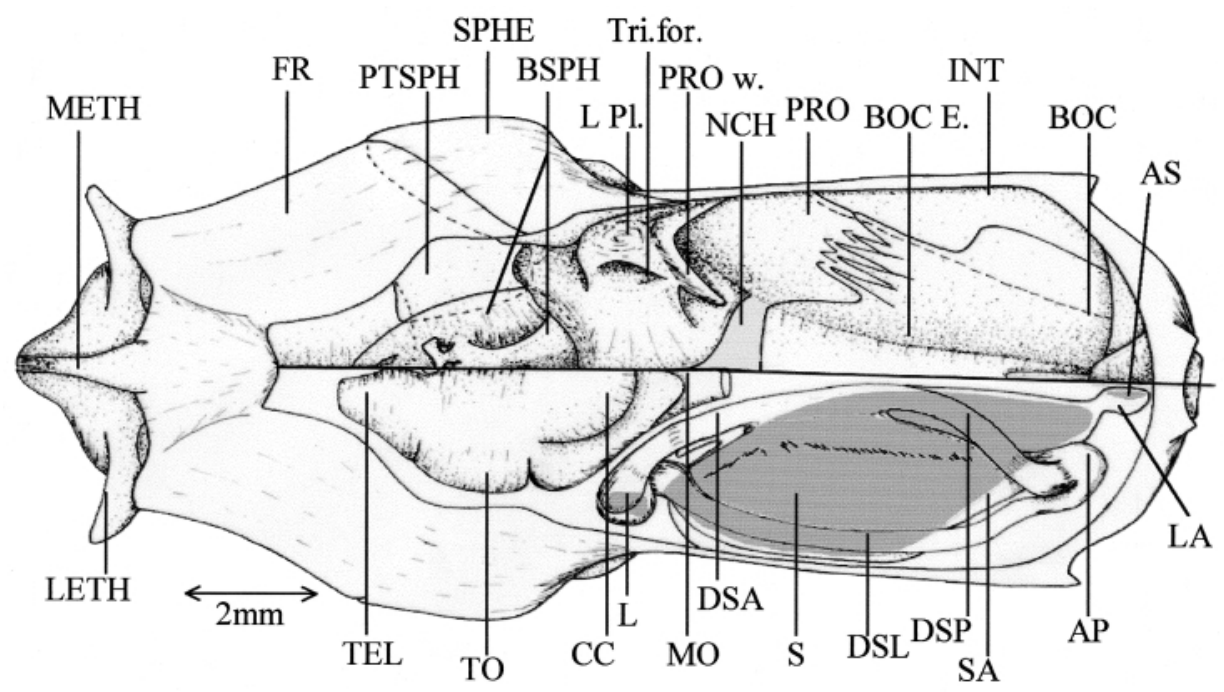

FIG. 2. Dorsal view of the inside of the neurocranium in Carapus boraborensis. The lower half indicates the positions of the inner ear and brain, while the upper half shows the skeletal floor of the otic capsule, with the brain and inner ear removed in the upper half. In dark grey: area of the three otoliths; in light grey: the notochord $(\mathrm{NCH})$. BOC E., basioccipital edge. For other abbreviations see Fig. 1.

and 2]. The left and right partes inferiores (sacculi and lagenae) occupy the ventral volume of the neurocranium: their sacculi are in contact above the basioccipital and their lagenae touch each other at the level of the foramen of the asterisci.

The two utricles (Fig. 4) are separated by the cerebellum and the anterior portion of the myelencephalon. Their recessus utriculi contain in front the lapilli arranged above the prootic plates surmounting the foramens of the facial and trigeminal nerves (Figs 1 and 2). Each recessus utriculi is conjoined by two semi-circular canals (Fig. 4): antero-dorsally, the anterior semi-circular canal (DSA) with the ampulla anterior and, postero-dorsally, the lateral semi-circular canal (DSL) with the ampulla lateralis. The utricle extends parallel along the medulla oblongata and is posteriorly in connection with the ampulla posterior from which issues vertically the posterior semi-circular canal (DSP). The latter joins the anterior semi-circular canal above the myelencephalon in a sinus superior (very short but very wide) ventrally connected to the median portion of the utricle. The horizontal semi-circular canal runs along the neurocranium and terminates medio-laterally at the posterior portion of the utricle. The horizontal and posterior semi-circular canals are supported respectively by the bony arches of the pterotics and epiotics [Fig. 1(b)]. Below the utricle is a very voluminous sacculus containing the sagitta. It is extended by the diverticulum of the lagena, containing the asteriscus [Figs 1(b) and 4]. The sagitta is well developed and bordered anteriorly by the internal prootic wing. Behind the wing, the position of the otolith is guided by the boundary created by the prootic bridge and basioccipital, which seem roughly to determine the shape of the proximal face of the sagitta (Fig. 2). In Onuxodon fowleri, the shapes of the membranous labyrinth and sagitta are related to the shape of the otic capsule [Fig. 4(b)]. The 


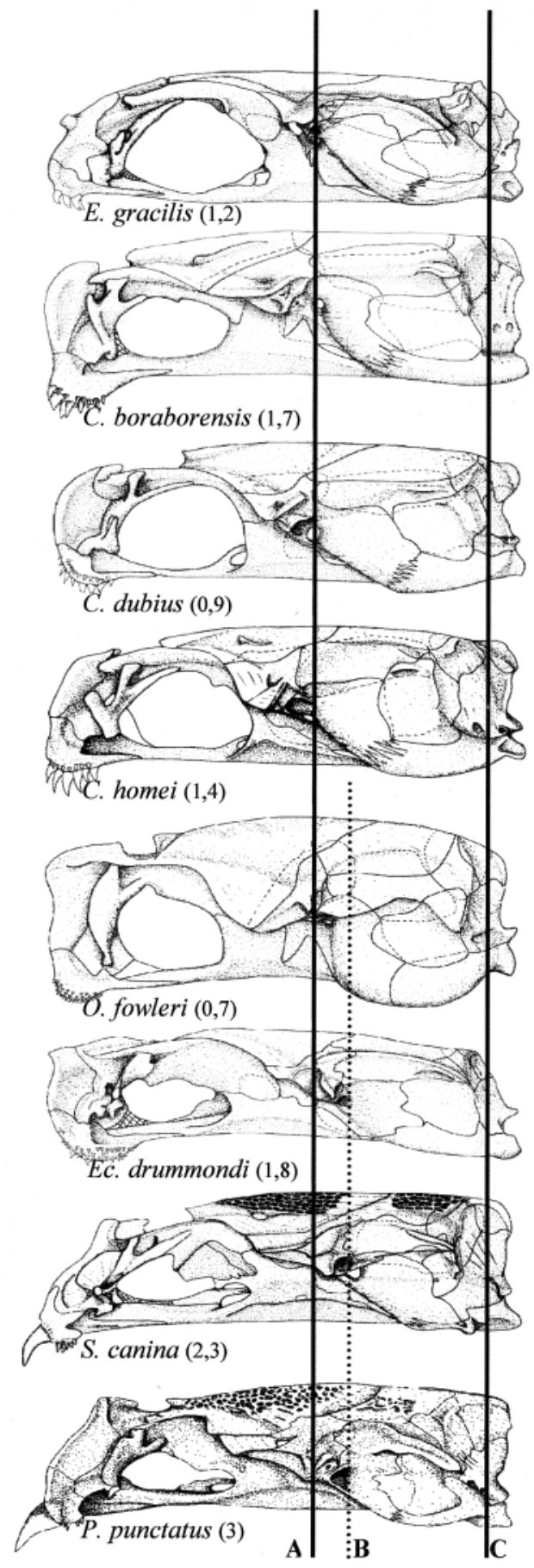

FIG. 3. Lateral view of the neurocranium in three carapid species. Solid lines (A and C) represent the length of the otic cavity in the upper four species. The dotted line (B) represents the anterior limit of the otic cavity in the lower three species. Onuxodon fowleri occupies an intermediate position. The numbers in parentheses indicate the actual lengths of the neurocrania in $\mathrm{cm}$. 

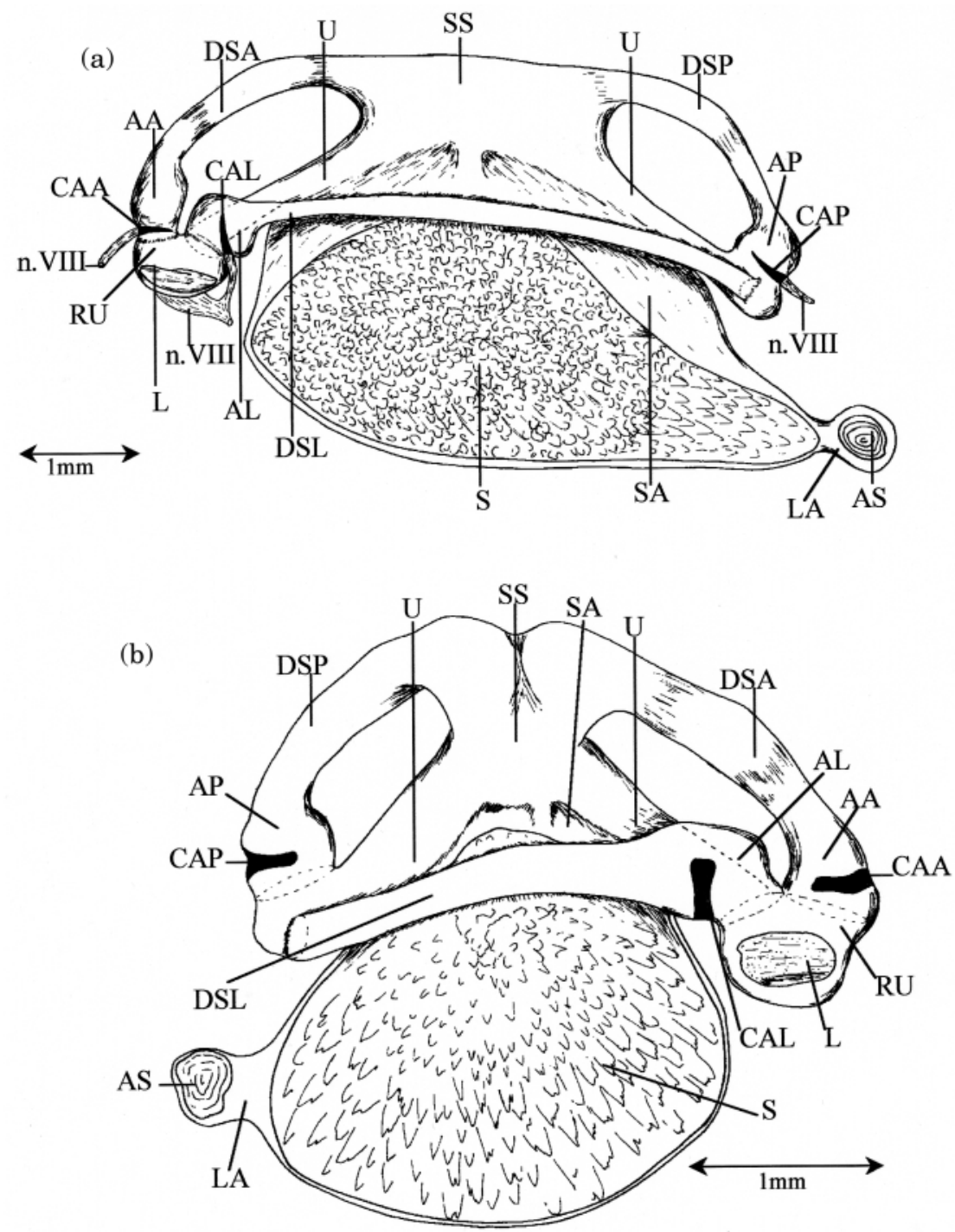

FIG. 4. Exterior lateral view of the left membranous labyrinth in Carapus boraborensis (a) and of the right one in Onuxodon fowleri (b). Scale bar $=1 \mathrm{~mm}$. CAA, crista ampulla anterior; CAL, crista ampulla lateralis; CAP, crista ampulla posterior. For other abbreviations see Fig. 1.

pars inferior and pars superior appear proportionately shorter and higher than in the other species examined. This appears mainly at the level of the sagitta, whose ventral edge follows the considerable bulge of the basioccipital and prootics.

\section{SAGITTA: MORPHOLOGY AND MORPHOMETRY}

Carapus boraborensis

The sagitta has the shape of a semi-convex lens, but its proximal face bulges slightly, in keeping with the ventral shape of the basioccipital and prootic (Fig. 5). The distal face bulges markedly at its centre. Seen from the outside, the 


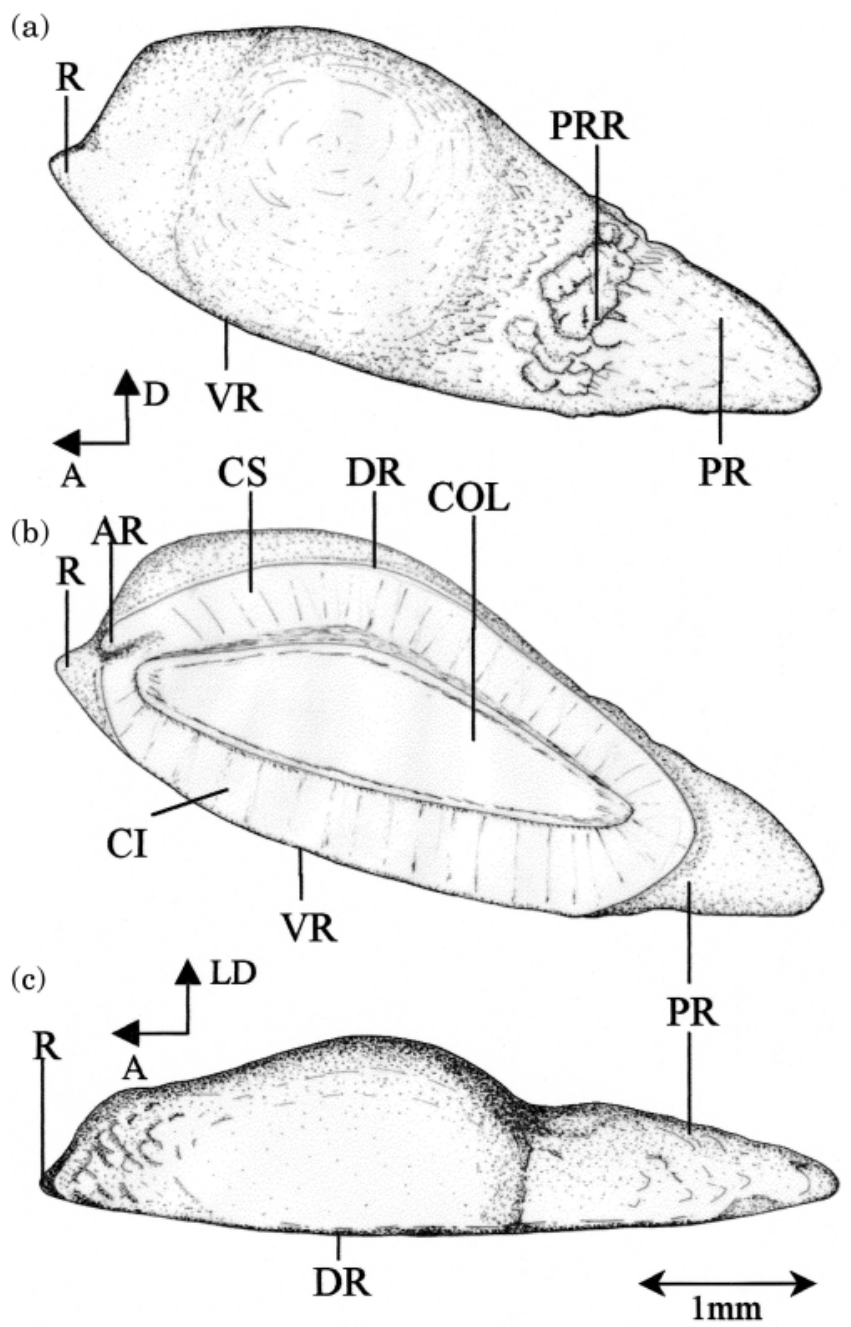

FIG. 5. Sagitta in Carapus boraborensis. Lateral views of the distal (a) and proximal (b) face and dorsal view (c). Scale bar=1 mm. A, anterior; AR, anti-rostrum; CI, crista inferior; COL, colliculum; CS, crista superior; D, dorsal; DR, dorsal ridge; LD, latero-dorsal; R, rostrum; PRR, post-rostrum rim; VR, ventral ridge. For other abbreviations see Fig. 1.

otolith seems to form two distinct parts [Fig. 6(a)]. In front, the sagitta looks like a half-sphere terminated by a very short rostrum, the antirostrum being very small and more readily discernible from the proximal side [Fig. 6(b)]. Behind this distal dome, the post-rostrum is particularly long with a pointed end. The distal dome seems to be formed by centrifugal radiation of crystals whose progressive lateral slanting confers to the sphere a tiered appearance [Fig. 6(e)]. Posteriorly, the limit between the distal dome and the post-rostrum is produced by a more distinct modification of the orientation of the needles. They are in a more horizontal plane at the level of the post-rostrum. Furthermore, in some specimens rougher crystalline forms may form at the beginning of the postrostrum [Fig. 6(f)]. The proximal face displays an elliptical sulcus occupied by a 
(a)

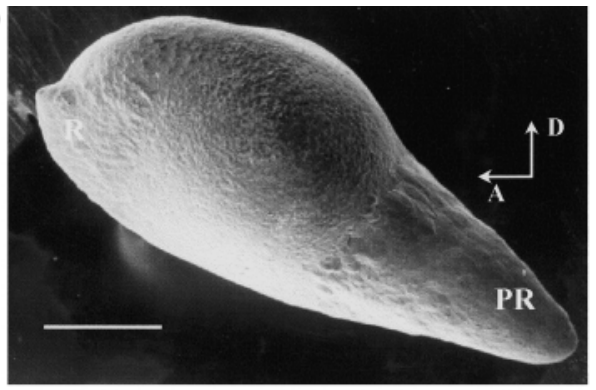

(c)

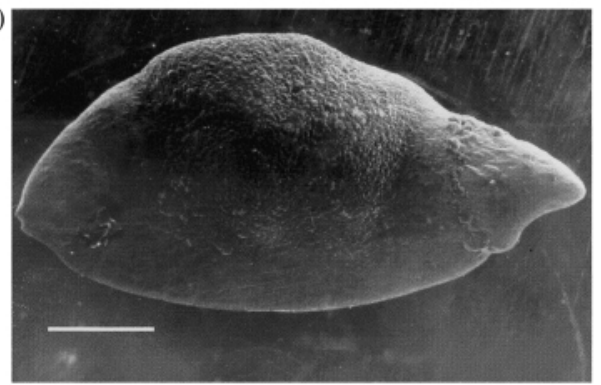

(e)

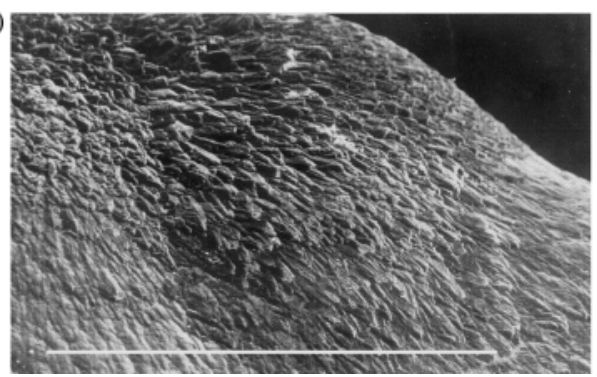

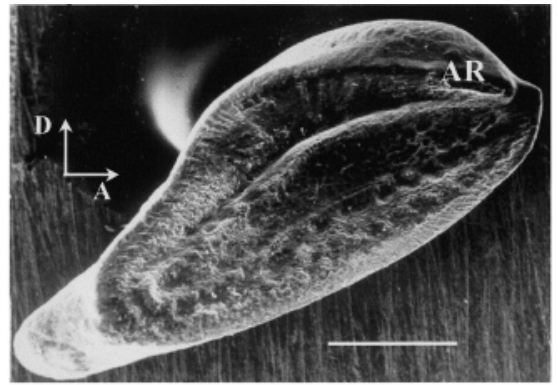

(b)

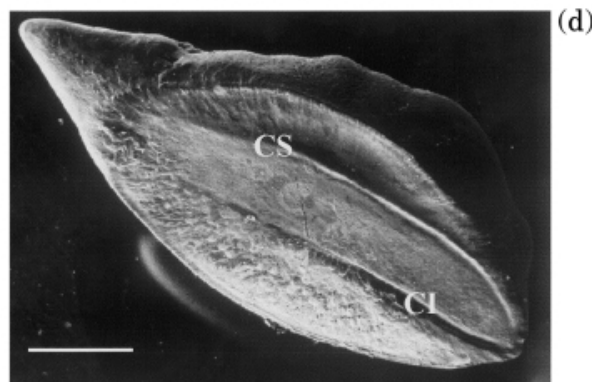

(d)

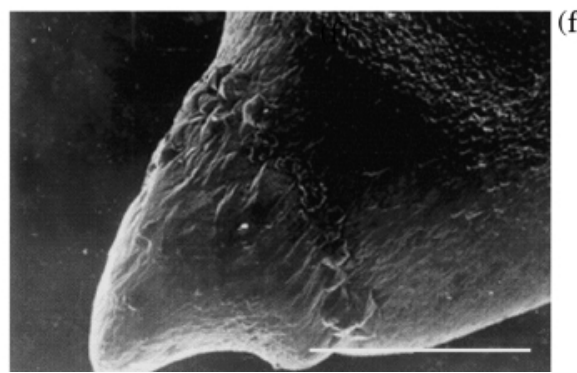

(f)

FIG. 6. Sagittae. Latero-distal view in Carapus boraborensis (a), C. homei (c). Latero-proximal view in C. boraborensis (b), C. homei (d). Enlargement of the distal face (e) and latero-proximal view of the post-rostrum (f) in C. homei. Scale bar $=1 \mathrm{~mm}$. For abbreviations see Fig. 1.

single colliculum [Fig. 6(b)]. Only on part of the post-rostrum does the sulcus extend backward. Only the crista superior is clearly marked.

\section{Carapus homei}

The sagitta of $C$. homei is very similar in shape to that of $C$. boraborensis, except for a few irregularities in the dome on the distal side [Fig. 6(c), (d)].

\section{Carapus dubius}

The sagitta of $C$. dubius is proportionately higher and more rounded. No antirostrum is distinguishable. Although present, the post-rostrum appears shorter but wider at its base, and its posterior extremity is rounder. It occupies a more anterior position in the otolith and seems to cover in part the distal dome, which results in an earlier rupture of the convexity of the otolith. As measured on the proximal side, the distances between the dorsal edge and crista superior on the one hand, and between the ventral edge and the crista inferior on the other, are greater than those observed in C. boraborensis and C. homei. 
(a)

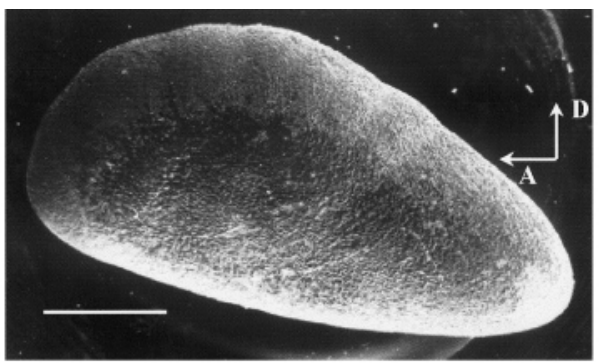

(c)

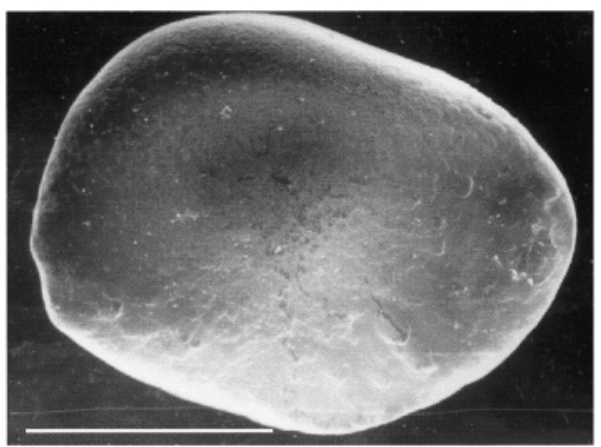

(e)

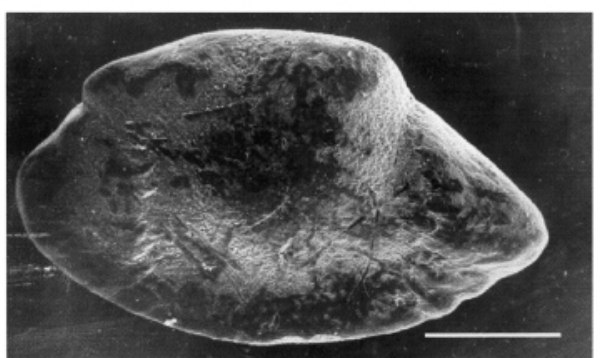

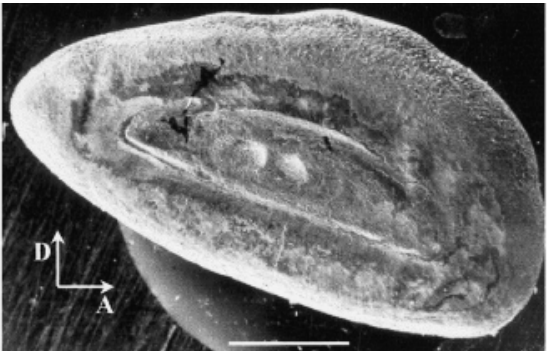

(b)
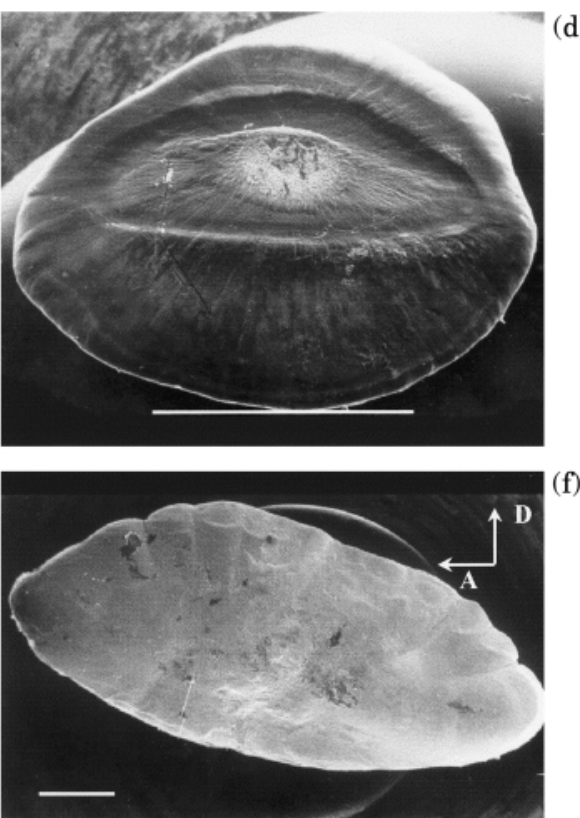

FIG. 7. Sagittae. Latero-distal view in Echiodon drummondi (a), Onuxodon fowleri (c), Encheliophis gracilis (e), and Pyramodon punctatus (f). Latero-proximal view in E. drummondi (b), O. fowleri (d). Scale bar $=1 \mathrm{~mm}$. For abbreviations see Fig. 1 .

Echiodon drummondi

This otolith also has a semi-convex shape [Fig. 7(a)]. It differs from that of the Carapus species by a post-rostrum that is not differentiated by a change in crystal orientation. The sagitta thus appears more regular and less tapered. On the proximal side, the elliptical sulcus occupies a depression [Fig. 7(b)]. It also displays a single colliculum marked by the presence of two slight depressions at its centre. The crista inferior is more visible and appears closer to the ventral face than in the above-mentioned species. The rostrum and antirostrum are not distinguishable.

\section{O. fowleri}

The sagitta of $O$. fowleri has almost the shape of a biconvex lens. The otolith appears proportionately shorter but much higher [Fig. 7(c), (d)]. This height seems mainly due to a more marked increase of the ventral part, accompanied by a distinct decentralization of the colliculum, which is closer to the dorsal edge. 
TABLE I. Relative thicknesses and width of the sagittae in different carapid species

\begin{tabular}{lrccc}
\hline Species & $n$ & $\begin{array}{c}\text { Otolith length/otolith } \\
\text { thickness }(\%)\end{array}$ & $n$ & $\begin{array}{c}\text { Otolith length/otolith } \\
\text { width }(\%)\end{array}$ \\
\hline Encheliophis gracilis & 4 & $34( \pm 1 \cdot 7)$ & 3 & $51( \pm 0 \cdot 5)$ \\
Carapus boraborensis & 10 & $25 \cdot 4( \pm 2)$ & 8 & $44( \pm 3 \cdot 8)$ \\
Carapus homei & 7 & $23 \cdot 2( \pm 0 \cdot 75)$ & 7 & $49 \cdot 5( \pm 0 \cdot 5)$ \\
Carapus dubius & 3 & $23 \cdot 6$ & 2 & $62 \cdot 5( \pm 2 \cdot 5)$ \\
Echiodon drummondi & 2 & $22 \cdot 5$ & 2 & $43 \cdot 2$ \\
Onuxodon fowleri & 5 & $27( \pm 1 \cdot 2)$ & 4 & $79 \cdot 5( \pm 6)$ \\
Pyramodon punctatus & 1 & 16 & 1 & $43 \cdot 2$ \\
Snyderidia canina & 1 & 16 & 1 & 42 \\
\hline
\end{tabular}

The centre of the colliculum is occupied by a central protuberance [Fig. 7(d)]. It is just possible to distinguish a slight rostrum, but no antirostrum. The increased height of the otolith corresponds with the more rounded shape of the otic capsule floor.

Encheliophis gracilis

The sagitta of this species resembles that of the Carapus species [Fig. 7(e)]. It differs from the latter by a more marked protuberance of the distal face, which confers a more compact appearance.

Pyramodon punctatus and Sagitta canina

The sagittae of these two species are characterized by a more or less regular oval shape without a developed rostrum or post-rostrum. There is no marked protuberance of the distal face, just a few irregularities [Fig. 7(f)].

\section{Morphometry}

The ratio of the thickness of the sagitta to its length measured along the antero-posterior axis is greatest for Encheliophis gracilis (Table I). It is between 21 and $25 \%$ for the Carapus species and Echiodon drummondi, whereas S. canina and $P$. punctatus have relatively thin sagittae $(16 \%)$. Onuxodon fowleri, with its rounded sagitta and comparatively high length-to-thickness ratio $(27 \%)$, would seem to have deepened at the expense of lengthening.

In addition, the otoliths of $C$. dubius and $O$. fowleri are proportionately the deepest. Their depths represent, respectively, 62.5 and $79.5 \%$ of the length whereas this ratio is between 42 and $51 \%$ in other species.

\section{DISCUSSION}

In carapid species, the inner ear is organized essentially like that of teleosts in general (Platt \& Popper, 1981; Popper, 1982; Nolf, 1985), and the shape of the sagitta is roughly of the paracanthopterigian type (Nolf, 1985). This means a relatively flat proximal face, an almost absent excisura, a rostrum and a sulcus that are very inconspicuous. Yet the inner ears of the carapid vary in size and in the dimensions of their constituents. In each case the features must reflect a 
compromise between several functions, but they must also be determined by various lifestyle-linked environmental factors. These multiple influences could translate as different ecomorphological types characterized by certain proportions, shapes, and sizes.

In most non-otophysine teleosts (Platt, 1973; Dale, 1976; Popper, 1977), the two membranous labyrinths are separated clearly by the metencephalon and myelencephalon, located in the otic region. In carapid, the otic region is occupied only slightly by the posterior brain; this allows considerable development of the membranous labyrinths (Fig. 1). The pars inferior is particularly well developed and seems dorsally to push away the pars superior, which means that the height of the pars superior is shorter, the sinus superior is broader, and the utricilus is narrower than in other teleosts (Grassé, 1958; Dale, 1976; Popper \& Coombs, 1980; Platt \& Popper, 1981; Popper, 1982). However, the observed differences in the size and shape of the semi-circular canals in teleosts do not seem to be linked to any fish mode of living (Platt \& Popper, 1981; Jensen, 1994). The development of the pars inferior also appears laterally, to the extent that the sacculi and lagenae occupy ventrally the entire otic region and meet in the sagittal plane (Fig. 2). The lagena, by its medio-posterior position and its connection to the sacculus by a thin diverticulum that isolates the asteriscus, differs from that illustrated by Dale (1976) and Popper (1982). According to the latter, the lagena of most non-otophysine teleosts (e.g. beryciforms, clupeomorphs) also communicates with the sacculus by a small opening, but in a postero-dorsal position. In other groups such as the Thunnidae and especially the Salmonidae, the lagena extends the sacculus posteriorly, which is contrary to the situation in the carapid where these two otosacs communicate by a wide opening (Popper, 1982).

The large size of the pars inferior seems due principally to hyper-development of the sagitta. According to Platt \& Popper (1981) and Popper \& Edds-Waltson (1995), the sagitta and asteriscus are the otoliths showing the greatest variability in the teleost ear. Both structure are involved in hearing (Pannella, 1980; Popper \& Coombs, 1980; Popper, 1982; Fay, 1984). The movements of the otolith produce a shearing action in the ciliary bundles of the macula sensory hair cells, thus causing mechanical stimulation of the ear (Dijkgraaf, 1960; Sand \& Michelsen, 1978; Popper \& Coombs, 1980; Popper \& Edds-Waltson, 1995). According to Gauldie (1988), the auditory capacity of fish could be determined in part by a lever system between the sagitta and its macula. The efficacy of this lever would depend on the ratio of the size of the macula to that of the otolith. More than size, the difference in density between the otolith and the neurocranium must be a determining factor in the movements of the otolith with respect to the rest of the body, and thus also in hearing. A massive otolith could be considered immobile during acoustic stimulation, while the body moves around it (de Vries, 1950; Popper, 1982). Otoliths were not weighed in this study. However, a thicker otolith gives intuitively a greater inertia and more pronounced shearing action on the macula hair cells. If the gravity is ignored, the inertia is proportional to the product of the mass and the radius. Firstly, the mass should be higher in a thicker otolith. Secondly, the radius between the otolith centre of gravity and the macula is inevitably longer in a thick otolith than in a thinnest. The very voluminous sagitta of carapid species might produce 
pronounced shearing actions and be linked to a special aptitude to perceive sound. This aptitude may have developed in these fish in parallel with the otophysical structures evidenced by Courtenay \& McKittrick (1970) and assumed to produce sounds (sonic muscles, hypertrophied third rib pair, ligament between the first epipleural rib and the swimbladder). Furthermore Encheliophis gracilis and the Carapus species, which possess the thickest otoliths, are also the species in which the third rib pair is the most developed and fused with the fourth (Markle \& Olney, 1990). Onuxodon species, characterized by a rocker bone in front of the swimbladder and by third and fourth rib pairs that are well developed but independent of each other, possess an otic cavity and sagittae distinguishable by their height. However, no sound recordings have been made for these different species.

Like all functional structures in an organism (Barel, 1984; Liem, 1993), the otic capsule and stato-acoustic system must have a shape and organization that represent a compromise between different needs and functions (swimming, hearing, equilibration, etc.) On the other hand, Motta \& Kotrschal (1992), Motta et al. (1995) have stressed the influence of environmental factors in the construction of an organism. The various carapid species display otic capsules and sagittae whose shapes and sizes can be related to the ecological niches of the fish. The otic cavities (Fig. 3) are proportionately larger in commensal species (C. boraborensis, C. homei and C. dubius) and parasitic ones (Encheliophis gracilis) than in benthic (Echiodon drummondi) and pelagic species ( $S$. canina and $P$. punctatus). These differences coincide with the thickness data for the sagittae studied (Table I). S. canina and P. punctatus, which live in open water, have the thinnest otoliths in the shortest otic cavities, whereas the parasitic species Encheliophis gracilis, with its lesser mobility, possesses one of the largest otic cavities and the thickest otolith. Nolf (1980) likewise reports that the sagittae of Encheliophis vermicularis (another recognized parasitic species, Markle \& Olney, 1990) are thicker than those of Carapus species.

Several factors, probably interlinked, may explain this relationship between the inner ear and the ecological niche. Firstly, the shape of the sagitta in pelagic species could be an element contributing to making the neurocranium lighter, thus reducing energy expenditure during swimming. Furthermore, the shape of the sagitta in $S$. canina and $P$. punctatus resembles closely that of other fast swimmer paracanthopterygians such as the Gadidae (Dale, 1976), the Merluccidae (Lombarte \& Fortuno, 1992), and the Macrouridae (Lombarte \& Morales-Nin, 1995). In benthic, commensal and parasitic species, the swimming constraint is obviously weaker. Therefore, it does not act as a restricting factor on the sagitta development. This is reinforced by thick otoliths found in the well known benthic Congridae (Nolf, 1985). Secondly, the commensal and parasitic carapid species have thinner cranial bones and thicker otoliths than the pelagic species. The inertia of their sagittae should be greater, with respect to the movements of the cranium. This difference in inertia might lead to more efficient perception for the commensal and parasitic species than for the pelagic and benthic species. The presence of a more or less developed post-rostrum in the Carapus and Encheliophis species might, in addition, reinforce the lever-arm involved in these shearing actions (Gauldie, 1988). These various adaptations could prove useful to species that must perceive sounds through the body of a 
host. This relationship between otolith thickness and functional adaptation to an environment is also mentioned by Nolf (1985) who noted that 'similarities are evident in the outline and thickness of the otoliths' in two unrelated benthic teleosts (Ophidiiformes and Congridae). The benthic species Echiodon drummondi has a thicker sagitta than $S$. canina and $P$. punctatus, but it also has a proportionately smaller otic cavity than the parasitic and commensal species. This suggests that Echiodon drummondi might be capable of hiding in crevices or burying itself in the substratum like other ophidiiform species (Greenfield, 1968; Trott, 1970). On the other hand, Berdar et al. (1995) observed that E. dentatus, a Mediterranean species, might also be able to seek shelter inside sea cucumbers.

Lastly, it is interesting to note the similarities between $O$. fowleri and C. dubius, which share the same lifestyle. Both hide between the mantle and shell of bivalves (Markle \& Olney, 1990; Castro-Aguirre et al., 1996; Parmentier et al., $2000 a, b)$. They both have particularly high sagittae, proportionately the highest among all the carapid species studied here (Table I). It would seem that the decreased length of the otolith has been compensated for by a development in height, this development occurring differently according to the species. According to Gauldie (1990), ' the effect of the physical contact between otolith and skull is to restrict growth at the ventral edge of the otolith'. The shape of the basioccipital in $O$. fowleri and $C$. dubius seems to determine the mode of development of the sagitta. In $O$. fowleri, a proportionately deeper basioccipital is accompanied by increased growth of the ventral area limited by the crista inferior [Fig. 7(d)]. In C. dubius, the basioccipital shows no distinctive feature and resembles those of $C$. boraborensis and $C$. homei. On the other hand, the deepening of the otolith in this species is due to more ample development of the dorsal area, limited by the crista superior.

\section{CONCLUSION}

Although no sound recordings have been made with the carapid species studied here, there appears in these fish a relationship between the auditory structures and some other anatomical features believed to produce sounds. The largest otic cavity, the widest sacculus and sagitta surrounded by the thinnest bones, are present in those species with the most highly developed vertebral parapophyses. These structures, both auditory and otophysical, are most developed in those species that are not entirely free-swimming, i.e. with a commensal or especially a parasitic lifestyle.

We thank Y. Chancerelle and J. Algret (CRIOBE, Moorea, French Polynesia) and J. M. Ouin (Biological Station, Laing Island, Papua New Guinea) for helping to obtain living carapid. J. Hislop (Fisheries Research Services, Marine Laboratory Aberdeen), Y. Machida (University of Kyoto, Japan), and Dr M. McGrouther (Australian Museum, Australia) for providing specimens of Echiodon drummondi, S. canina, and P. punctatus respectively. G. Goffinet and N. Decloux helped with the SEM study. D. Nolf provided interesting remarks. This work was supported by grant no. 1.4560 .96 from the Belgian 'Fonds National de la Recherche Scientifique'.

\section{References}

Barel, C. D. N. (1984). Form-relations in the context of constructional morphology-the eye and the suspensorium of lacustrine Cichlidae (Pisces: Teleostei) with a 
discussion on the implication for phylogenetic and allometric form interpretation. Netherlands Journal of Zoology 34, 439-502.

Berdar, A., Capecchi, D., Costa, F., Giordano, D., Mento, G. \& Spalletta, B. (1995). Pesci parassiti e pseudoparassiti dei mari italiani. Rivista di Parassitologia 12, 453-465.

Castro-Aguirre, J. L., Garcia-Dominguez, F. \& Balart, E. F. (1996). Nuevos hospederos y datos morfométricos de Encheliophis dubius (Ophidiiformes: Carapidae) en el Golfo de California, México). Revista de Biologia Tropical 44, 753-756.

Courtenay, W. R. (1971). Sexual dimorphism of the sound producing mechanism of the striper cusk-eel, Rissola marginata (pisces: Ophiidae). Copeia 1971, 259-268.

Courtenay, W. R. \& McKittrick, F. A. (1970). Sound-producing mechanisms in carapid fishes, with notes on phylogenetic implications. Marine Biology 7, 131-137.

Dale, T. (1976). The labyrinth mechanoreceptor organs of the cod Gadus morhua L. (Teleostei: Gadidae). Norwegian Journal of Zoology 24, 85-128.

Dijkgraaf, S. (1960). Hearing in bony fishes. Proceedings of the Royal Society of London 152, $51-54$

Fay, R. R. (1984). The goldfish ear codes the axis of acoustic particle motion in three dimensions. Science 225, 951-953.

Gauldie, R. W. (1988). Function, form and time-keeping properties of fish otoliths. Comparative Biochemistry and Physiology 91, 395-402.

Gauldie, R. W. (1990). Phase differences between check ring locations in the orange roughy otolith (Hoplostethus atlanticus). Canadian Journal of Fisheries and Aquatic Sciences 47, 760-765.

Grassé, P. P. (1958). L'oreille and ses annexes. In Traité de Zoologie, Vol. 13 (Grassé, P. P., ed.), pp. 1063-1098. Paris: Masson.

Greenfield, D. W. (1968). Observations on the behavior of the basketweave cuk-eel Otophidium scrippsi Hubbs. California Fish \& Game 54, 108-114.

Howes, G. J. (1988). The cranial muscles and ligaments of macrourid fishes (Teleostei: Gadiformes); functional, ecological and phylogenetic inferences. Bulletin of the British Museum of Natural History (Zoology) 54, 1-62.

Jensen, J. C. (1994). Structure and innervation of the inner ear sensory organs in an otophysine fish, the upside-down catfish (Synodontis nigriventris David). Acta Zoologica (Stockholm) 75, 143-160.

Kotrschal, K., van Staaden, M. J. \& Huber, R. (1998). Fish brains: evolution and environmental relationships. Reviews in Fish Biology and Fisheries 8, 373408.

Liem, K. F. (1993). Ecomorphology of the teleostean skull. In The Skull, Vol. 3. Functional and Evolutionary Mechanism (Hanken, J. \& Hall, B. K., eds), pp. 422-452. Chicago: University of Chicago Press.

Lombarte, A. \& Castellon, A. (1991). Inter and intraspecific otolith variability in the genus Merluccius as determined by image analysis. Canadian Journal of Zoology 69, 2442-2449.

Lombarte, A. \& Fortuno, J. M. (1992). Differences in morphological features of the sacculus of the inner ear of two hakes (Merluccius capensis and M. paradoxus, Gadiformes) inhabits from different depth of sea. Journal of Morphology 214, 97-107.

Lombarte, A. \& Morales-Nin, B. (1995). Morphology and ultrastructure of saccular otoliths from five species of the genus Coelorinchus (Gadiformes: Macrouridae) from the Southeast atlantic. Journal of Morphology 225, 179-192.

Lowenstein, O. (1971). The labyrinth. In Fish Physiology, Vol. 5 (Hoar, W. S. \& Randall, D. J., eds), pp. 207-240. New York: Academic Press.

Markle, D. F. \& Olney, J. E. (1990). Systematics of the Pearlfish (Pisces: Carapidae). Bulletin of Marine Science 47, 269-410.

Motta, P. J. \& Kotrschal, K. M. (1992). Correlative, experimental and comparative evolutionary approaches in ecomorphology. Netherlands Journal of Zoology 42, $400-415$. 
Motta, P. J., Clifton, K. B., Hernandez, P. \& Eggold, B. T. (1995). Ecomorphological correlates in ten species of subtropical seagrass fishes: diet and microhabitat. Environmental Biology of Fishes 44, 37-60.

Nolf, D. (1980). Etude monographique des otolithes des Ophidiiformes actuels and révision des espèces fossiles (Pisces, Teleostei). Mededelingen van de Werkgroep voor Tertiaire en Kwartaire Geologie 17, 71-195.

Nolf, D. (1985). Otolithi piscium. In Handbook of Paleoichthyology, Vol. 10A (Schultze, L., ed.), 145 pp. New York: Gustav Fisher Verlag.

Nolf, D. (1993). A survey of perciform otoliths and their interest for phylogenetic analysis, with an iconographic synopsis of the Percoidei. Bulletin of Marine Sciences 52, 220-239.

Pannella, G. (1980). Growth pattern of fish sagittae. In Skeletal growth of acquatic organisms: Biological records of environmental change (Rhoad, D. C. \& Lutz, R. A., eds), pp. 519-560. New York: Plenum.

Parmentier, E., Castillo, G., Chardon, M. \& Vandewalle, P. (2000a). Phylogenetic analysis of the pearlfish tribe Carapini (Pisces: Carapidae). Acta Zoologica 81, 293-306.

Parmentier, E., Castro-Aguirre, J. L. \& Vandewalle, P. (2000b). Morphological comparison of the buccal apparatus in two bivalve commensal Teleostei: Encheliophis dubius and Onuxodon fowleri (Carapidae, Ophidiiformes). Zoomorphology 120, 29-37.

Platt, C. (1973). Central control of postural orientation in flatfish. I. Dependance on central rather than peripheral changes. Journal of Experimental Biology 59, 491-521.

Platt, C. \& Popper, A. N. (1981). Fine structure and function of the ear. In Hearing and Sound Communication in Fishes (Tavolga, W. N., Popper, A. N. \& Fay, R. R., eds), pp. 2-37. New York: Springer-Verlag.

Popper, A. N. (1977). A scanning electron microscopic study of the sacculus and lagena in the ears of fifteen species of teleost fishes. Journal of Morphology 153, 397-417.

Popper, A. N. (1982). Organization of the inner ear and auditory processing. In Fish Neurobiology, Vol. 1 (Northcutt, E. G. \& Davis, R. E., eds), pp. 126-178. Ann Arbor: University of Michigan Press.

Popper, A. N. \& Coombs, S. (1980). Auditory mechanisms in teleost fishes. American Scientist 68, 429-440.

Popper, A. N. \& Edds-Waltson, P. L. (1995). Structural diversity in the inner ear of teleost fishes: implications for the connections to the Mauthner cell. Brain Behaviour Evolution 46, 131-140.

Sand, O. \& Michelsen, A. (1978). Vibration measurements of the perch saccular otolith. Journal of Comparative Physiology 123, 85-89.

Schuijf, A. (1981). Models of acoustic localization. In Hearing and Sound Communication in Fishes (Tavolga, W. N., Popper, A. N. \& Fay, R. R., eds), pp. 267-310. New York: Springer-Verlag.

Strasburg, D. W. (1965). Description of the larvae and familial relationships of the fish Snyderidia canina. Copeia 1965, 20-24.

Tavolga, W. N. (1971). Sound production and detection. In Fish Physiology, Vol. 5 (Hoar, W. S. \& Randall, D. J., eds), pp. 135-205. New York: Academic Press.

Trott, L. B. (1970). Contribution of the biology of carapid fishes (Paracanthopterygian: Gadiformes). University of California Publication in Zoology 89, 1-41.

Trott, L. B. (1981). A general review of the pearlfishes (Pisces, Carapidae). Bulletin of Marine Sciences 31, 623-629.

de Vries, H. (1950). The mechanics of the labyrinth otoliths. Acta Oto-Laryngology 38, 262-273.

Williams, J. T. (1983). Synopsis of the pearlfish subfamily Pyramodontinae (Pisces: Carapidae). Bulletin of Marine Sciences 33, 846-854.

Wilson, R. R. Jr (1985). Depth-related changes in sagitta morphology in six macrourid fishes of the Pacific and Atlantic ocean. Copeia 1985, 1011-1017. 